\title{
A Survey On The Constitution Forms Of Library And Information Terms In English And Vietnamese
}

\author{
Nguyen Thi Thanh Hai, PhD. \\ Hanoi University of Home Affairs, Vietnam \\ DOI: 10.29322/IJSRP.11.07.2021.p11550 \\ http://dx.doi.org/10.29322/IJSRP.11.07.2021.p11550
}

\begin{abstract}
:
The article focuses on understanding and examining the constitution forms of library and information terms in English and in Vietnamese. At the same time, the author would like to evaluate the similarities and differences in the method to constitute library and information terms in English as well as in Vietnamese. The results have shown that in both language, most terms are formed by word combination, which is a popular way of word formation and has the largest productive ability of all languages. However, because English is a metamorphic language, so it can be said that the forms of term constitution in English is more diverse.
\end{abstract}

Key words: constitution forms, library and information terms, words, phrases, compounding, affixations, noun phrases, verb phrases.

\section{The article}

Library and information terms are words or phrases expressing concepts, subjects, phenomena in library and information science including activities in cooperation with subjects, organs, products and related services in terms of library and information. Based on the results of a preliminary survey of terminology research works in different fields, it can be seen that scientific terminology in general is made up of two basic types of vocabulary units: words and phrases. As a subsystem of Vietnamese terminology system, library and information terms possess the same characteristics.

The article focuses on understanding and examining the constitution forms of library and information terms in English and in Vietnamese. At the same time, based on the survey, the author would like to evaluate the similarities and differences in the method to constitute library and information terms in both languages, contributing to the development of information science and library in Vietnam.

\section{Constitution of library and information terms as a "word"}

\section{English library and information terms as a word}

English is a type of transfigurative and multi-syllable language. Each word in English is made up of one or several morpheme combined together in accordance with certain principles. As cited by Bloomfield: "Morpheme is the smallest meaningful unit and/or has its own value in terms of grammar." It can also be understood that morpheme is the last unit when analyzing the composition units of library and information terms in English.

English library and information terms are composed of single words, compounds and derivation words. From Bloomfield's viewpoints, English single words are independent morphemes, a word is equivalent to a morpheme, e.g. card (thẻ), entry (đề mục), subject (chủ đề), v.v...

English library and information terms are mainly formed in the following ways 


\section{(i). Affixations}

Affixations is a way to combining a root and an affix (prefix, suffix, and infix) to form new words. Affixes function as elements that constitute derivational terms and each affix, when joining in word formation have a specific meaning and a stable combination. Statistics has shown that derivational terms are mainly derived from prefixes and suffixes in which suffixes are more predominant way.

\section{(ii). Compounding}

Compounding is the method of combining two or more morphemes in a certain order to produce new words compound words (mainly combinations of root words). This is a commonly used method in languages. . For examples: copyright: bản quyền; Editor-in-chief: tổng biên tập, content note: chú giải nội dung.

In addition, the transference method is also used to create English library and information terms.

\section{Vietnamese library and information terms as a word}

In the thesis, we surveyed Vietnamese library and information terms in two types of word formation: single words and compound words. In Vietnamese, single word is "a combination of sounds and meanings. According to Nguyen Tai Can, "compound words are a unit of co-ordination with its internal organization: in the composition of a word compound, it's easy to find at least three sounds that are combined by one relationship or another. Based on Nguyen Tai Can's definition, compound words can be divided into two main categories, i.e.: subordinate compounds and coordinate compounds.

Similarly, Vietnamese library and information compound terms is formed by subordinate compounds and coordinate compounds. Terms as subordinate compounds are isometric terms formed on the basis of coordinate relations and they are equal in terms of structures, types and semantic contents. For examples, nguồn gốc, sao chép, bình luận, v.v... The terms as subordinate compounds are terms composed of two components: one of which is a major element, and one is a subordinate element that detailing, shading the main element. For example: printer, photocopier.

\section{Constitution of library and information terms as a phrase}

\section{Library and information terms in English as a phrase.}

"Phrase is a small group of words standing together as a conceptual unit, typically forming a component of a clause." (Oxford Dictionaries). In English, there are such common phrases as noun phrases, verb phrases, adjective phrases, adverbial phrases and prepositional phrases. In the scope of the article, we do not try to discover their characteristics or differentiate among them but focus on how they are constituted.

Results from studies on terms conducted recently have shown that most of terms are noun phrases. Verb phrases has accounted for a small number and there are almost no terms as adverbial phrases or prepositional phrases. On the basis of survey on library and information terms in English, it can be seen that English library and information terms also possess the same features.

Statistics have shown that library and information terms as noun phrases are the dominant in the source language (accounting for over 80\%). For examples: catalog management, ccataloging in source, associative retrieval system, multiple word subject heading.

The number of library and information terms as verb phrases are small, for about $14 \%$ and virtually no telocentric is an adjective, adage, or preposition, for examples: reissue under a new title, computerize the publishing process.

\section{Library and information terms in Vietnamese as a phrase}

The same as in English, phrases are vocabulary units that can be used for creating sentences in Vietnamese. A phrase is a unit formed by a combination of words, which are composed of two or more words, including at least one real word. 
A phrase also acts as an independent element to form a sentence, which has a semantic meaning as a word. Therefore, a phrase is considered as an equivalent unit to words. Based on the results of the preliminary survey of library and information terms in Vietnamese, it is said that there are almost no types of word structure as adverbial or prepositional phrases.

Accordingly, statistics have shown that library and information terms as noun phrases in Vietnamese account for 77\%. For examples: công nghệ/thông tin /điện tủ, dịch vultra cúu/tuơng tác, hệ thống/quản lý/thu viện, co sở/ dũ liệu/biểu ghi/thu muc, co sớ/ dĩ liệu/ báo/ tạp chil điện tử; and verb phrases are of approximately 4,47\%, for examples: đánh giá/vốn/tài liệu, trao đổi/dũ liệu/điện tủ, xủ lý/dũ liệu/tập trung xác định/tùr/khóa/theo tài liệu.

\section{Evaluation on the similarities and differences on the composition of library and information terms in English and} in Vietnamese

Regarding the constitution of terms, the results of the survey and data analysis show that English library and information terms are formed according to basic word formation methods in English, that is the method to use affixation, parts of speech transition and compounding from which single words, derivative words, compound words and phrases are formed. At the same time, it can be seen that Vietnamese library and information terms are also formed based on common method of words constitution in Vietnamese, that is transition of parts of speech and compounding to form terms as single words, compound words. and phrases.

The common thing between English and Vietnamese library and information terms is that they are created in a common form of structures in a language - transcription. In terms of vocabulary units, both English and Vietnamese library and information terms have terminological units consisting of single words, compound words and phrases; Most of them are subordinate compounds and phrases.

The difference between English and Vietnamese library and information terms is that in addition to the method of transcription, English use mode of affixations but Vietnamese does not. This is due to the difference in their type of language. English is a metamorphic language, so it can be said that the method of word formation in English is quite diverse, facilitating the lexical development of this language. In Vietnamese, library and information terms are mainly formed by the method of compounding, which is the most popular way of word formation and has the largest productive ability of all languages. 


\section{REFERENCES}

1. Brown R.W. (2003), Composition of Scientific Words, Smithsonian Institution Press, Washington.

2. Diep Quang Ban (2010), Dictionary of Linguistics Terms, Vietnam Education Publishing House..

3. Ha Quang Nang (2009), "Characteristics of Vietnamese terms (Episode 1), Lexicography \& Encyclopedia, No 11, 32-38.

4. Ha Quang Nang (2010), The development of Vietnamese lexicology in the latter half of the $20^{\text {th }}$ century, Social Sciences Publishing House, Hanoi.

5. Hoang Van Hanh (1983), The formation and development of Vietnamese terms, Journal of Linguistics, No 4, 26-34.

6. Ingo Plag (2002), Word-formation in English, Cambridge University Press

7. Jacson H., Amvela E.Z. (2007), Words, Meaning and Vocabulary: An Introduction to Modern English Lexicology, 2nd Edition, Continuum London - New York

8. Nguyen Duc Ton (2012), A research and survey on Vietnamese Terms for the development of Law on Languages in Vietnam, , Research work.

9. Nguyen Huu Viem (2000), English - Vietnamese Dictionary of Library and Information Terms as Nouns (2000), Culture of Vietnamese Ethnic Groups Publishing House Co., Ltd.

10. Nguyen Minh Hiep (2007), English for specific purposes: Library and Information Science, Vietnam Education Publishing House.

11. Nguyen Minh Hiep (2009), Library and Information, Theoretical Background, Vietnam Education Publishing House

12.Pham T.L.H, Lam V.T., Nguyen T.N. (1996), ALA: English - Vietnamese Glossary of Library and Information Science, Publisher: Galen Press, Ltd.

13. Reitz, Joan M. (2005), Dictionary for Library and Information Science, Westport, Connecticut: Libraries Unlimited.

14. English - Vietnamese Dictionary of Library and Information (2010), Published by General Sciences Library of Hochiminh City.

15. Vietnamese - English Dictionary of Library and Information (2013), Published by General Sciences Library of Hochiminh City.

\section{AUTHORS}

First Author: Nguyen Thi Thanh Hai, PhD, specialized in Comparative and Contrastive Linguistics.

Lecturer of English at Hanoi University of Home Affairs.

Email: thanhhai78@gmail.com 